\title{
Possible activation of murine T lymphocyte through CD98 is independent of interleukin 2 /interleukin 2 receptor system
}

\author{
Hiroshi Komada ${ }^{1,2}$, Akiyo Imai $^{2}$, Emi Hattori ${ }^{2}$, Morihiro Ito ${ }^{1}$, Hideki Tsumura ${ }^{3}$, Toshiko Onoda ${ }^{2}$, Mariko \\ Kuramochi $^{2}$, Machiko Tani ${ }^{2}$, Kanako Yamamoto ${ }^{2}$, Mizuho Yamane ${ }^{2}$, Mitsuo Kawano ${ }^{1}$, Machiko Nishio, \\ Kimitaka Yuasa ${ }^{1}$, Myles O’Brien ${ }^{4}$, Hidetaka Yamamoto ${ }^{2}$, Jun Uematsu' ${ }^{2}$, Masato Tsurudome ${ }^{1}$ and Yasuhiko \\ Iто $^{1}$ \\ ${ }^{1}$ Department of Microbiology, Mie University School of Medicine, Tsu, Mie 514-8507; ${ }^{2}$ Department of Microbiology, Suzuka Univer- \\ sity of Medical Science, Suzuka, Mie 510-0293; ${ }^{3}$ Division of Laboratory Animal Resources, National Research Institute for Child \\ Health and Development, Setagaya, Tokyo 157-8535; and ${ }^{4}$ Mie Prefectural College of Nursing, Tsu, Mie 514-0116, Japan \\ (Received 14 November 2005; and accepted 26 January 2006)
}

\begin{abstract}
CD98 is a widely expressed cell surface heterodimetric protein of $125 \mathrm{kDa}$. Its expression is upregulated during lymphocyte activation induced by mitogen, superantigen, conventional antigen, and a combination of phorbol myristate acetate (PMA) and ionomycin. However, the role of CD98 in the immune system is not so well understood. The role of CD98 in murine T lymphocyte proliferation was investigated, especially in correlation with the interleukin 2 (IL-2)/interleukin 2 receptor (IL-2R) system. Monoclonal antibody $(\mathrm{mAb})$ directed against murine CD98 heavy chain (mCD98HC) suppressed the proliferation of lymphocytes stimulated with concanavalin A (Con A). Anti-mCD98HC mAb did not suppress the expression of IL-2R $\alpha$. Anti-IL-2R $\alpha$ mAb, which suppressed DNA synthesis, did not inhibit the expression of CD98HC. Murine IL-2 (recombinant), which induced considerable DNA synthesis by lymphocytes stimulated with a sub-optimal dose of Con A, did not induce CD98HC expression in lymphocytes. In addition, anti-mCD98HC mAb did not inhibit the production of IL-2 by lymphocyte stimulated with Con A. Taken together with these findings, it was speculated that the CD98 system is independent of the IL-2/IL-2R system in murine $\mathrm{T}$ lymphocyte activation.
\end{abstract}

Lymphocyte activation process is regulated by many factors such as transferrin $(2,7,22,23)$, insulin $(8,9)$, interleukin 2 receptor (IL-2R) (CD25) (13) and CD98 (6), and by lymphokines such as interleukin 2 (IL-2) $(13,20,23,31)$. IL-2 is known as a T cell growth factor $(13,20,31)$, and IL-2 plays a role in the late $\mathrm{G}_{1}$ stage (15). IL-2 binds its receptor (IL-2R) (13), and the binding induces proliferation of T lymphocytes. IL-2R is composed of 3 subunits, namely,

Address correspondence to: Prof. Yasuhiko Ito Department of Microbiology, Mie University School of Medicine, Tsu, Mie 514-8507

Tel/Fax: +81-59-231-5008

E-mail: ito@doc.medic.mie-u.ac.jp
IL-2R $\alpha$ (CD25), IL-2R $\beta$ (CD122) and IL-2R $\gamma$ (CD132) chains. IL-2R $\alpha(55 \mathrm{kDa})$, known as Tac antigen (28), is specific for IL-2R, while IL-2R $\beta$ $(70-75 \mathrm{kDa})$ is common for IL-2 and IL-15 mediated signaling, and IL-2R $\gamma(65-70 \mathrm{kDa})$ is a common subunit of IL-2R, IL-4R, IL-7R, IL-9R and IL-15R. CD98, originally termed $4 \mathrm{~F} 2$ antigen, is a $125 \mathrm{kDa}$ type II transmembrane protein composed of an $80 \mathrm{kDa}$ glycosylated heavy chain and a $45 \mathrm{kDa}$ nonglycosylated light chain (CD98LC) $(6,24,25)$. CD98 is expressed on all activated cells, all cell lines and all known malignant or transformed cells (6, 30). CD98 is a multifunctional protein and its roles are as follows: amino acid transporter $(1,19)$, integrin regulator $(4,25)$, fusion regulator $(11,18)$, in- 
ducer of osteoclast (10), and mouse embryogenesis (27). CD98 is the same molecule as fusion regulatory protein-1 (FRP-1) (17). CD98 also plays an important role in immune cell function and is known as the activated lymphocyte antigen $(6,31)$. The expression of CD98 on T cells (3) and B cells (30) increases during activation by mitogens such as phytohemagglutinin (PHA) and Con A, superantigens such as Staphylococcus aureus enterotoxin A (SEA), conventional antigen such as Tetanus toxoid, and PMA plus inomycin, or lipopolysaccharide. It was found that CD98 also plays a role in the late $G_{1}$ stage of lymphocyte proliferation (3).

Nineteen $\mathrm{mAbs}$ directed against $\mathrm{mCD} 98 \mathrm{HC}$ were produced (26), and $2 \mathrm{mAbs}$ were found to have inhibitory effects on lymphocytes stimulated with Con A. In the present investigation, the role of CD98HC in murine $\mathrm{T}$ lymphocyte activation was analyzed, especially in correlation with the IL-2/IL-2R system.

\section{MATERIALS AND METHODS}

Cells. Lymphocytes were isolated from spleens of male C57BL/6 mice of 6-8 weeks old using $\mathrm{NH}_{4} \mathrm{Cl}$ lysing buffer. The lymphocytes were cultured at $1 \times$ $10^{6}$ cells $/ \mathrm{mL}$ in $96-$ well round-bottom culture plates in $0.2 \mathrm{~mL}$ of RPMI1640 medium supplemented with $10 \%$ fetal calf serum (FCS) at $37^{\circ} \mathrm{C}$ in a humidified atmosphere with $5 \% \mathrm{CO}_{2}$.

Experiments using mice were carried out according to the guideline for animal experiments in Mie University School of Medicine.

Antibodies and reagents. Monoclonal antibodies against murine CD98HC (26) and an isotype matched control mAb (131A: against NP protein of human parainfluenza type 4A virus) (14) are described elsewhere. MAb against murine IL-2R $\alpha$ (anti-Tac) was purchased from BD Biosciences (Tokyo, Japan) and was dialyzed against sterile PBS to remove $\mathrm{NaN}_{3}$. FITC-labelled mAbs to murine IL-2R $\alpha$ was from BD Biosciences. Con A and recombinant murine IL-2 were purchased from Calbiochem (La Jolla, California, USA) and Peprotech (Rocky Hill, New Jersey, USA), respectively.

$M A b$ production and purification. MAb against mCD98HC (26-24: IgG2a) and control mAb were produced using VectraCell-Single Use Bioreactor System (BioVectra, Charlottetown, PE, Canada). The hybridoma cells were cultured for about 3 weeks in DMEM supplemented with sodium pyruvate, non-essential amino acids, NCTC109 medium and $10 \%$ FCS.

The supernatant was harvested by centrifugation and filtrated with $0.22 \mu \mathrm{m}$ pore filter. The filtrated supernatant was subjected to protein $G$ column chromatography. The eluate was dialyzed against PBS, and the concentration was determined by measuring optical density at 280 and $260 \mathrm{~nm}$.

Labeling of $m A b$ with FITC. Labeling of antimCD98HC mAb (11-19) was carried out using the antibody labeling system FITC Labeling Kit K8010 (American Qualex Antibodies, San Clemente, California, USA) according to the manufacturer's protocol.

Proliferation assay. DNA synthesis was measured by cell proliferation ELISA with BrdU Kit (Roche Diagnostics GmbH, Penzberg, Gremany) according to the manufacturer's protocol. BrdU $(20 \mu \mathrm{L} /$ well $)$ labeling solution was added to the lymphocyte culture, and the lymphocytes were incubated for $4 \mathrm{~h}$ at $37^{\circ} \mathrm{C}$. The plates were centrifuged at $300 \mathrm{~g}$ for $15 \mathrm{~min}$, the labeling medium removed by aspiration, and the cells were dried using a hair-dryer. Fix Denat $(200 \mu \mathrm{L} /$ well $)$ was added to the plates and they were incubated for $30 \mathrm{~min}$ at room temperature. Fix Denat was removed by decantation, and anti-BrdUPOD working solution $(100 \mu \mathrm{L} /$ well $)$ was added. Subsequently, the plates were incubated for $60 \mathrm{~min}$ at room temperature. The antibody solution was removed, and the cells were rinsed three times with $200 \mu \mathrm{L} /$ well of washing solution. The substrate solution $(100 \mu \mathrm{L} /$ well $)$ was added to the plates, which were incubated for appropriate times at room temperature. The reaction was stopped by the addition of $1 \mathrm{~N} \mathrm{H}_{2} \mathrm{SO}_{4}(25 \mu \mathrm{L} /$ well $)$. The absorbance at $450 \mathrm{~nm}$ was measured with an immunoreader.

FACS analysis. Flow cytometric analysis was performed using FACScan (Becton Dickinson, Tokyo, Japan). For FACS analysis, the lymphocytes were cultured in $3 \mathrm{~mL}$ of the medium in a round-bottom glass tube.

Measurement of IL-2. IL-2 was assayed using IL-2 assay Kit (Biosource International, Camarillo, California, USA) according to the manufacturer's method. Fifty $\mu \mathrm{L}$ of supernatant and $50 \mu \mathrm{L}$ of biotinated anti-IL-2 solution were added to each microplate well, and incubated for $2 \mathrm{~h}$ at $37^{\circ} \mathrm{C}$. The solution was thoroughly decanted and the wells were washed 4 times with the washing buffer. A hundred $\mu \mathrm{L}$ of Streptavidine-HRP solution was added to each well 
and incubated for $30 \mathrm{~min}$ at room temperature. The solution was thoroughly decanted and washed, and $100 \mu \mathrm{L}$ of stabilized chromogen was added. Subsequently, the plates were incubated in the dark for appropriate times. A hundred $\mu \mathrm{L}$ of stop solution was added and the absorbance at $450 \mathrm{~nm}$ was read with an immunoreader.

\section{RESULTS}

Anti-mCD98HC $m A b$ inhibits the activation of lymphocytes stimulated with Con A

To investigate the function of $\mathrm{CD} 98 \mathrm{HC}$ in immune cell responses, we analyzed the effects of antimCD98HC mAbs on lymphocyte DNA synthesis induced by Con A. In this experiment, anti-mCD98HC $\mathrm{mAb}$ and Con A were added simultaneously. The lymphocytes were cultured with the optimum concentration of Con A $(0.7 \mu \mathrm{g} /$ well $)$ for DNA synthesis (data not shown) and DNA synthesis was measured at $72 \mathrm{~h}$ of stimulation. Out of $19 \mathrm{mAbs}$ against murine CD98HC, 2 mAbs had an inhibitory effect on the proliferation (data not shown). Anti-mCD98HC $\mathrm{mAb}(26-24)(15 \mu \mathrm{g} / \mathrm{well})$ suppressed the mitogenesis by Con A to about $40 \%$ (Fig. 1). In contrast, the isotype matched control $\mathrm{mAb}(\operatorname{IgG} 2 \mathrm{a})(131 \mathrm{~A}$ : antiNP protein of human parainfluenza type $4 \mathrm{~A}$ virus) had no inhibitory effect on the proliferation (Fig. 1).
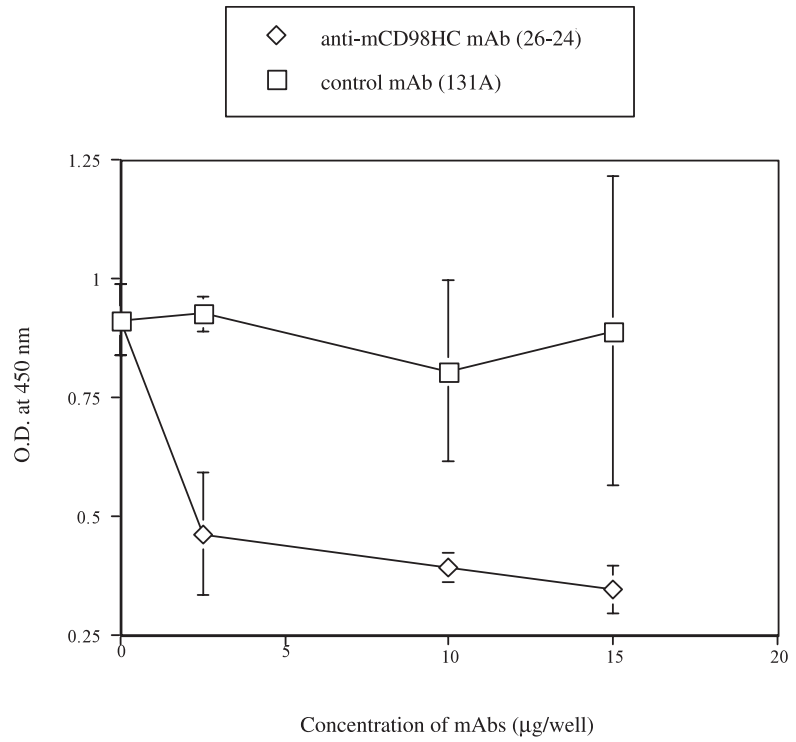

Fig. 1 Effect of anti-mCD98HC on lymphocyte stimulation. Anti-mCD98HC mAb (26-24) inhibited DNA synthesis by lymphocytes stimulated with Con $A$ to about $40 \%$, but control mAb (131A) had no inhibition on DNA synthesis. DNA synthesis was measured at $72 \mathrm{~h}$ of stimulation. The data represents mean \pm SD of 3 experiments.
We used mAb (26-24) (15 $\mu \mathrm{g} /$ well) in the following experiments.

\section{Relation between CD98HC and IL-2/IL-2R}

Firstly, we analyzed the kinetics of IL-2R $\alpha$ expression, CD98HC expression and IL-2 production of Con A-stimulated lymphocytes. The expression of IL-2R $\alpha$ already increased in the early stage, and considerable expression of IL-2R $\alpha$ was observed at $24 \mathrm{~h}$ of stimulation (Fig. 2A: red line). CD98HC was up-regulated by Con A-stimulation within several hours, and the maximum expression was also at $48 \mathrm{~h}$ post stimulation (Fig. 3A: red line). Resting lymphocytes produced no IL-2. When lymphocytes were stimulated with Con A, the production of IL-2 was observed within several hours and the maximum production of IL-2 $(967 \mathrm{pg} / \mathrm{mL})$ was at $48 \mathrm{~h}$ post stimulation (Fig. 4).

The $\mathrm{mAb}$ against mCD98HC scarcely inhibited the expression of IL-2R $\alpha$ (Fig. 2B: black line).

In the following experiments, we analyzed the effect of anti-IL-2R $\alpha \mathrm{mAb}$ on DNA synthesis and on the expression of $\mathrm{CD} 98 \mathrm{HC}$ at $72 \mathrm{~h}$ and $48 \mathrm{~h}$ of Con A-stimulation, respectively. Anti-IL-2R $\alpha \mathrm{mAb}$ $(15 \mu \mathrm{g} /$ well) reduced Con A-induced DNA synthesis to about $60 \%$ (data not shown). Anti-IL-2R $\alpha \mathrm{mAb}$ did not inhibit the expression of CD98HC (Fig. 3B: red line), and control $\mathrm{mAb}$ did not inhibit the expression (Fig. 3B: blue line). From these results, it was indicated that CD98HC and IL-2R $\alpha$ have little functional interaction during proliferation.

Low concentration of Con A $(0.1 \mu \mathrm{g} / \mathrm{well})$ did not induce notable DNA synthesis by lymphocytes (data not shown). However, addition of recombinant IL-2 (rIL-2) $(1000 \mathrm{pg} / \mathrm{mL})$ induced significant DNA synthesis by lymphocytes stimulated with sub-optimal dose of Con A (data not shown). In the following experiment, we analyzed the effect of rIL-2 on the expression of $\mathrm{CD} 98 \mathrm{HC}$ at $48 \mathrm{~h}$ of stimulation. A sub-optimal dose of Con A induced only a slight expression of CD98HC (Fig. 3C: red line). Recombinant IL-2 $(1000 \mathrm{pg} / \mathrm{mL})$ did not enhance the expression of $\mathrm{CD} 98 \mathrm{HC}$ on lymphocytes stimulated with a sub-optimal dose of Con A (Fig. 3C: blue line). Recombinant IL-2 itself did not induce CD98HC expression (Fig. 3C: green line). Nonstimulated lymphocytes did not express $\mathrm{CD} 98 \mathrm{HC}$ at $48 \mathrm{~h}$, and the figure is almost the same as that of rIL-2 (data not shown).

Fig. 4 shows the effect of anti-mCD98HC mAb on the production of IL-2 at $48 \mathrm{~h}$. Anti-mCD98HC $\mathrm{mAb}$ lowered IL-2 production a little $(770 \mathrm{pg} / \mathrm{mL})$, and control $\mathrm{mAb}$ did also $(797 \mathrm{pg} / \mathrm{mL})$. Anti-mIL- 


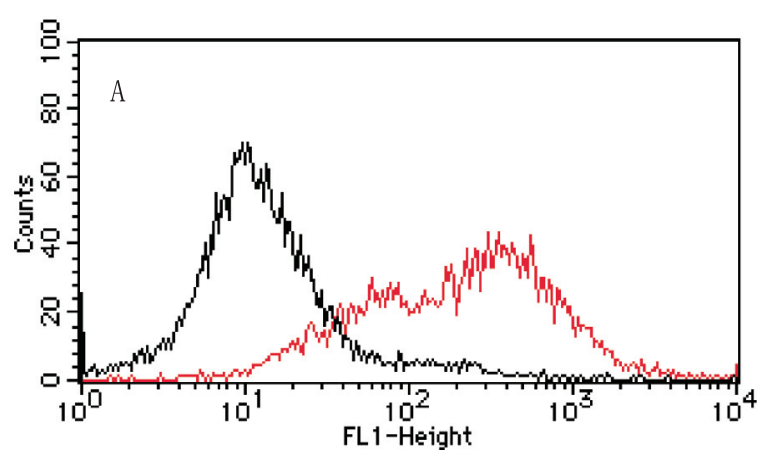

$\mathrm{IL}-2 \mathrm{R} \alpha$

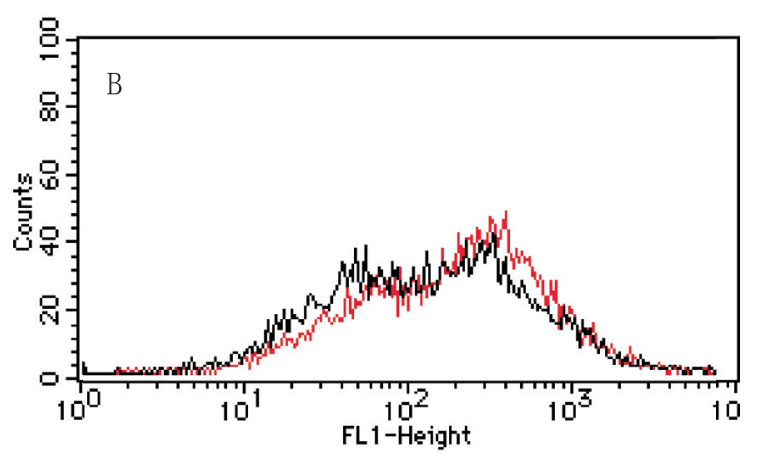

$\mathbb{L}-2 \mathrm{R} \alpha$

Fig. 2 Anti-mCD98HC mAb did not inhibit the expression of IL-2R $\alpha$. The representative result out of several experiments is shown. A: Non-stimulated lymphocytes (black line). Con A-stimulated lymphocytes measured at $24 \mathrm{~h}$ (red line): considerable expression of IL-2R $\alpha$ was observed. B: Anti$\mathrm{mCD} 98 \mathrm{HC} \mathrm{mAb}$ did not inhibit IL-2R $\alpha$ expression (black line). Control mAb had no inhibition (red line).

$2 \mathrm{R} \alpha \mathrm{mAb}$ lowered IL-2 production $(610 \mathrm{pg} / \mathrm{mL})$. These results show that anti-mCD98HC mAb had no effect on IL-2 production, indicating that the biochemical process of IL-2 production might not be controlled by the CD98HC system.

\section{DISCUSSION}

The inhibitory effect of anti-mCD98HC mAb was described by some investigators using mitogen-, superantigen- and nominal antigen-stimulated peripheral blood mononuclear cells (PBMC) $(3,6,21,31)$. However, the function of $\mathrm{CD} 98 \mathrm{HC}$ in immune cell responses has not been so well understood. The present investigation examines the role of $\mathrm{CD} 98 \mathrm{HC}$, especially on the correlation between the CD98 system and IL-2/IL-2R systems. Anti-mCD98HC mAb (26-24) suppressed Con A-stimulated lymphocyte response as much as $40 \%$, and the percentage of in-
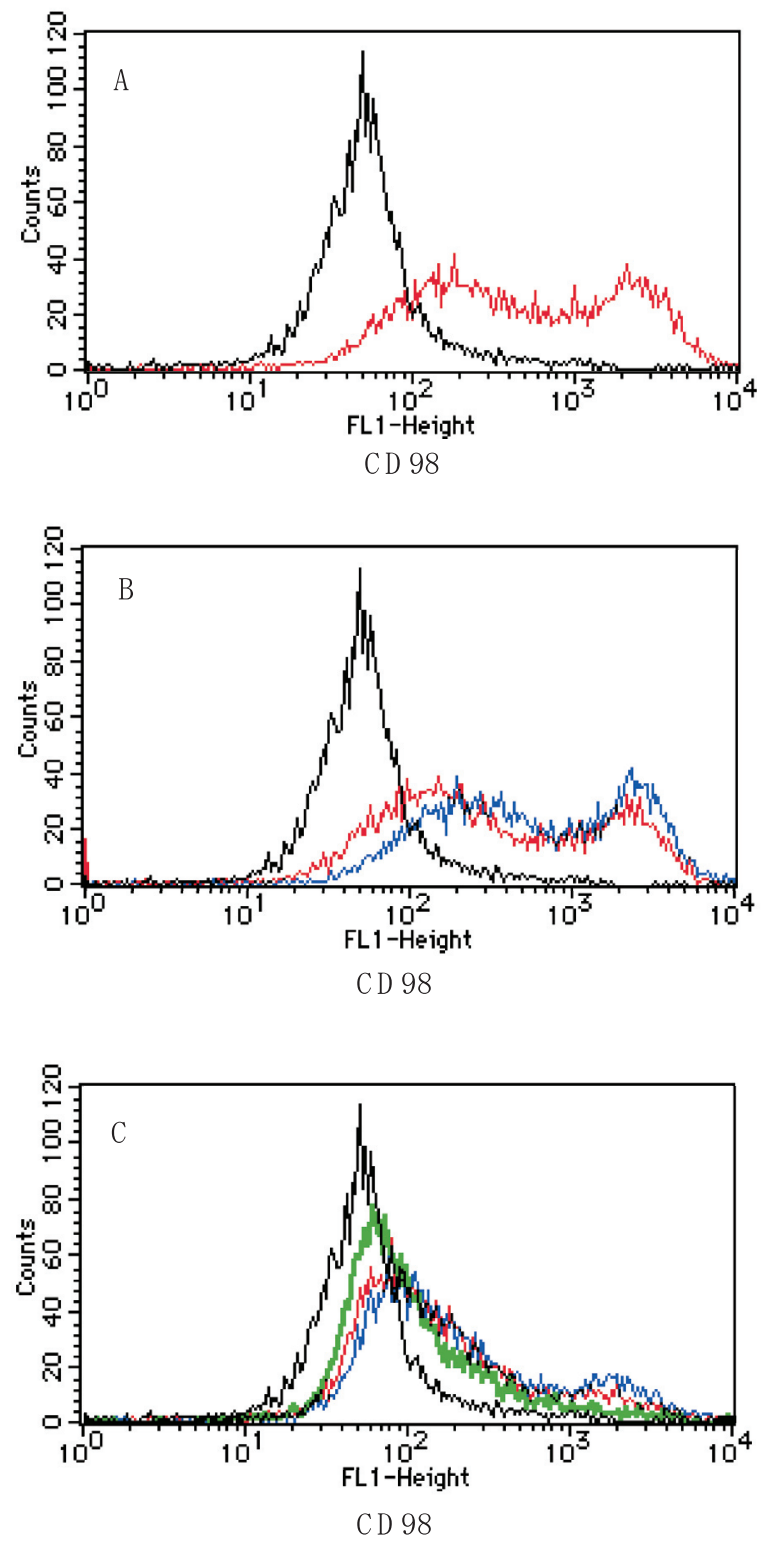

Fig. 3 Effects of anti-IL-2R $\alpha$ mAb and recombinant IL-2 on the expression of CD98HC. Anti-IL-2R $\alpha$ mAb did not inhibit CD98HC expression. Recombinant IL-2 (1000 pg/mL) did not enhance CD98HC expression in lymphocytes stimulated with a sub-optimal dose of Con $A$. The representative result out of several experiments is shown. A: Non-stimulated lymphocytes (black line) measured just after preparation. Con A-stimulated lymphocytes (red line) measured at $48 \mathrm{~h}$ : considerable expression of $\mathrm{CD} 98 \mathrm{HC}$ was observed. B: Nonstimulated lymphocytes (black line). Anti-IL-2R $\alpha$ mAb did not inhibit expression of CD98HC (red line). Control mAb had no inhibition (blue line). C: Non-stimulated lymphocytes (black line). Sub-optimal dose of Con A-stimulated lymphocytes (red line) at $48 \mathrm{~h}$ : little expression of CD98HC was observed. Sub-optimal dose of Con A- and rIL-2-stimulated lymphocytes (blue line): recombinant IL-2 did not enhance the expression of CD98HC. Lymphocytes stimulated with only rlL-2 (green line): little expression of CD98HC was observed. 


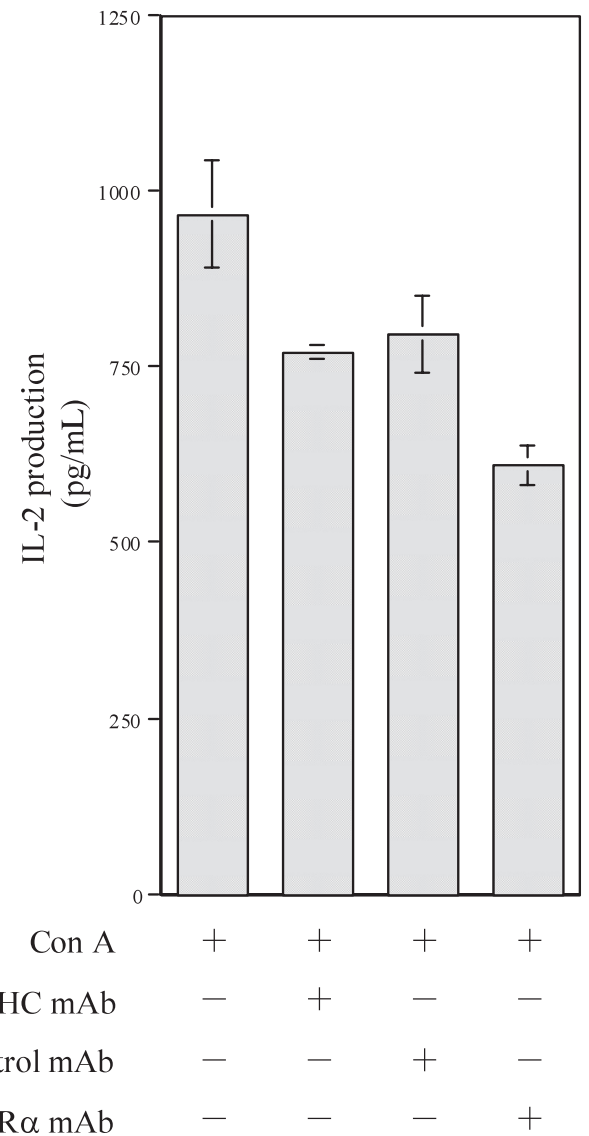

Fig. 4 Anti-mCD98HC mAb had no effect on IL-2 production. Anti-mCD98HC mAb lowered IL-2 production a little, but control $\mathrm{mAb}$ also lowered IL-2 production to the same concentration. Anti-mIL-2R $\alpha$ mAb lowered IL-2 production. These results indicated that anti-mCD98HC did not inhibit IL-2 production. IL-2 production was measured at $48 \mathrm{~h}$ of stimulation. The data represent mean \pm SD of 3 experiments.

hibition was about the same as that found by other investigators. Haynes et al. (6) reported that 4F2 antibody inhibited mitogen-induced tritium thymidine incorporation of PBMC by 50\%. Diaz et al. (3) reported that anti-CD98HC mAb (4F2) inhibited the superantigen response by as much as $80 \%$. The inhibition levels of rIL-2-mediated mitogenic response by anti-CD98HC mAb were varied from minimal to as much as $50 \%$ inhibition (3). Both mAb UM7F8 (anti-CD98HC) and 4F2 completely blocked the response to Tetanus toxiod (3). Exogeneous conventional antigen needs to be processed by antigen presenting cells (APC) such as monocytes, while superantigen and mitogen do not require processing for presentation to helper $\mathrm{T}$ cells, indicating that the degree of inhibition depends on the kind of stimulators.
In addition, 4F2 did not inhibit PBMC response to PMA plus ionomycin or rIL-2 (3), though CD98HC was expressed with stimulation of PMA plus ionomycin (29), indicating that the stimulation process without APC may not require CD98, and the CD98 system is involved in only a co-stimulatory process. Stonehouse et al. (21) showed that $\mathrm{mAb}$ to CD98 and CD147 showed an inhibitory effect when prepulsed on to the U937 cells, suggesting that the inhibitory effect was mediated by these molecules on the APC. Adhesion between U937 and $\mathrm{T}$ cells may be a prerequisite for proliferation. Diaz et al. (3) also showed the role of monocytes in the inhibition of anti-CD98HC mAb: they showed that treatment of PBMC with L-leucine methyl ester, which depletes phagocytic cells, abrogated the inhibitory effect of anti-CD98HC mAb on T cell proliferation. These results indicated that anti-CD98HC $\mathrm{mAb}$ acted on $\mathrm{APC}$, and $\mathrm{CD} 98 \mathrm{HC}$ played a role in presenting antigen on MHC class II molecules to $\mathrm{T}$ cells. CD98HC did not regulate the initial activation events involving the interaction between the APC and $\mathrm{T}$ cells. This is supported by the fact that antiCD98HC mAb does not affect $\mathrm{Ca}^{2+}$ fluxes by SEA. In addition, the fact that $4 \mathrm{~F} 2$ strongly inhibited $\mathrm{T}$ cell response even when added $18 \mathrm{~h}$ or more post stimulation, suggested that CD98 was not involved in early signaling, and acted on $\mathrm{T}$ cells in the late $\mathrm{G}_{1}$ phase. Anti-CD98HC mAb may block the binding of a certain molecule to CD98HC in monocytes, but not to $\mathrm{CD} 98 \mathrm{HC}$ in $\mathrm{T}$ cells. One of the candidate molecules was galectin 3 (5). Galectin 3 is secreted from monocytes but not from $\mathrm{T}$ cells. It was found that galectin 3 binds to CD98 and induces $\mathrm{Ca}^{2+}$ fluxes, and also activates monocytes and induces IL-1 secretion (16). Anti-CD98HC mAb may block monocyte auto-activation by galectin 3 .

In this study, anti-mCD98HC mAb neither inhibited IL-2 production nor IL-2R $\alpha$ expression induced by Con A. However, there is a disagreement concerning the effect of anti-CD98HC mAb on IL-2R $\alpha$ expression. Diaz et al. previously reported that antiCD98HC mAb inhibited IL-2R $\alpha$ expression induced by superantigen, but did not reduce expression of the IL-2 (3). A possible explanation for the discrepancy between our result and the result of the other investigator (3) is as follows: superantigen makes a bridge between the MHC class II molecule and the $\mathrm{T}$ cell receptor, but it does not bind to the cell membrane of the two cells, and this process may be important for the abrogation of IL-2R $\alpha$ expression of $\mathrm{T}$ cells. On the other hand, mitogen binds some part of the cell membrane of APC and T cells, and 
$\mathrm{T}$ cells may express IL-2R $\alpha$ independently of CD98HC of APC. The experimental result that PHA-induced blast cells cultured with rIL-2 were partially inhibited by anti-IL-2R $\alpha \mathrm{mAb}(3)$ is similar to our result that anti-IL-2R $\alpha$ mAb could suppress Con A-induced proliferation by as much as $40 \%$. Anti-CD98HC mAb did not block the proliferation of pre-activated lymphocytes (3), due to production of IL-2 and expression of IL-2R $\alpha$ in pre-activated lymphocytes. Pre-activated lymphocytes proliferate via the IL-2/IL-2R system, and the proliferation does not depend on the CD98HC system. From these results, it is inferred that the CD98 and IL-2/IL-2R systems are independent and that the CD98HC system is an additional secondary co-stimulating system in immune response.

\section{Acknowledgements}

A part of the present investigation was supported by a grant from the Japanese Ministry of Education, Culture, Sports, Science and Technology.

\section{REFERENCES}

1. Bertran J, Magagnin S, Werner A, Markovich D, Biber J, Testar X, Zorzono A, Kuhn LC, Palacin M and Murer H (1992) Stimulation of system $\mathrm{y}^{+}$-like amino acid transport by the heavy chain of human 4F2 surface antigen in Xenopus laevis oocytes. Proc Natl Acad Sci USA 89, 5606-5610.

2. Cotner T, Williams JM, Christenson L, Shapiro HM, Strom TB and Strominger J (1983) Simultaneous flow cytometric analysis of human $\mathrm{T}$ cell activation antigen expression and DNA content. $J$ Exp Med 157, 461-472.

3. Diaz LA, Friedman AW Jr, He X, Kuick RD, Hanash SM and Fox DA (1997) Monocyte-dependent regulation of T lymphocyte activation through CD98. Internatl Immunol 9, 1221-1231.

4. Diaz LA and Fox DA (1998) A role for CD98 in cellular activation. J Biol Reg Homeost Agents 12, 25-32.

5. Dong S and Hughes RC (1996) Galectin-3 stimulates uptake of extracellular $\mathrm{Ca}^{2+}$ in human Jurkat T-cells. FEBS Lett 395, 165-169.

6. Haynes BF, Hemler ME, Mann DL, Eisenbarth GS, Shelhamer J, Mostowshi HS, Thomas CA, Strominger JL and Fauci AS (1981) Characterization of a monoclonal antibody (4F2) that binds to human monocytes and a subset of activated lymphocytes. J Immunol 126, 1409-1414.

7. Haynes BF, Helmer ME, Cotner T, Mann DL, Eisenbarth GS, Strominger JL and Fauci AS (1981) Characterization of a monoclonal antibody (5E9) that defines a human cell surface antigen of cell activation. J Immunol 127, 347-351.

8. Helderman JH, Reynolds TC and Strom TB (1978) The insulin receptor as universal marker of activated lymphocytes. Eur J Immunol 8, 589-595.

9. Helderman JH and Strom TB (1979) Role of protein and RNA synthesis in the development of insulin binding sites on activated thymus-derived lymphocytes. J Biol Chem 254, 7203-7207.
10. Higuchi S, Tabata N, Tajima M, Ito M, Tsurudome M, Sudo A, Uchida A and Ito Y (1998) Induction of human osteoclastlike cells by treatment of blood monocytes with anti-fusion regulatory protein-1/CD98 monoclonal antibodies. J Bone Miner Res 13, 44-49.

11. Ito $\mathrm{Y}$, Komada H, Kusagawa S, Tsurudome M, Matsumura H, Kwano M, Ohta H and Nishio M (1992) Fusion regulation proteins on the cell surface: isolation and characterization of monoclonal antibodies which enhance giant polylkaryocyte formation in Newcastle disease virus-infected cell lines of human origin. J Virol 93, 5999-6007.

12. Komada H, Nakabayashi H, Hara M, Sawada M, Takahashi T, Shiomi T and Izutsu K (1985) Mechanism of interleukin-2medaited signaling and role of calcium in $\mathrm{T}$ cell mitogenesis. Immunol Invest 14, 435-442.

13. Komada H, Nakabayashi H, Hara M and Izutsu K (1996) Early calcium signaling and calcium requirements for the IL-2 receptor expression and IL-2 production in stimulated lymphocytes. Cell Immunol 173, 215-220.

14. Komada H, Tsurudome M, Ueda M, Nishio M, Bando H and Ito Y (1989) Isolation and characterization of monoclonal antibodies to human parainfluenza virus type 4 and their use in revealing antigenic relation between subtype $4 \mathrm{~A}$ and $4 \mathrm{~B}$. $\mathrm{Vi}$ rology 171, 28-37.

15. Leonard WJ, Depper JM, Uchiyama T, Smith KA, Waldmann TA and Greene WC (1982) A monoclonal antibody that appears to recognize the receptor for human T-cell growth factor: partial characterization of the receptor. Nature 300, 267269.

16. Liu FT, Hsu DK, Zuberi RI, Kawabata I, Chi EY and Henderson WR (1995) Expression and function of galectin-3, a beta-galactoside-binding lectin, in human monocytes and macrophages. Am J Pathol 147, 1016-1028.

17. Ohgimoto S, Tabata N, Suga S, Nishio M, Ohta H, Tsurudome M, Komada H, Kawano M, Watanabe N and Ito $\mathrm{Y}$ (1995) Molecular characterization of fusion regulatory protein-1 that induces multinucleated giant cell formation of monocytes and HIV gp160-mediated cell fusion: FRP-1 and 4F2/CD98 are identical molecules. J Immunol 155. 35853592.

18. Ohta H, Tsurudome M, Matsumura H, Koga Y, Morikawa S, Kawano M, Kusagawa S, Komada H, Nishio M and Ito Y (1994) Molecular and biological characterization of fusion regulatory proteins (FRPs): anti-FRP mAbs induced HIV-mediated cell fusion via an integrin system. EMBO J 13, 20442055.

19. Rossier G, Meier C, Bauch C, Summa V, Sordat B, Verrey F and Kuhn LC (1999) LAT2, a new basolateral 4F2hc/CD98associated amino acid transporter of kidney and intestine. $J$ Biol Chem 274, 34948-34954.

20. Smith KA (1980) T-cell growth factor. Immunol Rev 51, 337-357.

21. Stonehouse TJ, Woodhead VE, Herridge PS, Ashrafian H, George M, Chain BM and Katz DR (1999) Molecular characterization of U937-dependent T-cell co-stimulation. Iтmunology 96, 35-47.

22. Sutherland R, Delia D, Schnider C, Newman R, Kemshead J and Greaves M (1981) Ubiquitous cell-surface glycoprotein on tumor cells is proliferation-associated receptor for transferrin. Proc Natl Acad Sci USA 78, 4515-4519.

23. Trowbridge IS and Omary MB (1981) Human cell surface glycoprotein related to cell proliferation is the receptor for transferrin. Proc Natl Acad Sci USA 78, 3039-3043.

24. Tsurudome M, Ito M, Takebayashi S, Okumura K, Kawano M, 
Kusagawa S, Komada H and Ito Y (1999) Primary structure of the light chain of FRP-1/CD98/4F2 predicts a protein with multiple transmembrane domains that is almost identical to the amino acid transporter E16. J Immunol 162, 2462-2466.

25. Tsurudome $M$ and Ito $Y$ (2000) Function of fusion regulatory proteins (FRPs) in immune cells and virus-infected cells. Crit Rev in Immunol 20, 167-196.

26. Tsumura H, Kawano M, Tajima M, Kusaura T, Kozuka Y, Yoshimura S, Komada H, Tsurudome M, Nishio M, Kusagawa S, Shimura K and Ito Y (1999) Isolation and characterization of monoclonal antibodies directed against murine FRP-1/CD98/4F2 heavy chain: murine FRP-1 is an alloantigen and amino acid change at 129 is related to the alloantigenicity. Immunol Cell Biol 77, 19-27.

27. Tsumura H, Suzuki N, Saito H, Kawano M, Otake S, Kozuka Y, Komada H, Tsurudome M and Ito Y (2003) The targeted disruption of CD98 gene results in embryonic lethality. BBRC 308, 847-851.
28. Uchiyama T, Broder S and Waldman TA (1981) A monoclonal antibody (anti-Tac) reactive with activated and functionally mature human T cells: I. Production of anti Tac monoclonal antibody and distribution of $\mathrm{Tac}^{+}$cells. J Immunol 126, 1393-1397.

29. Warren A, Patel K, Miyamoto Y, Wygant JN, Woodside DG and Mcintyre BW (2000) Convergence between CD98 and integrin-mediated T-lymphocyte co-stimulation. Immunology 99, 62-68.

30. Yagita H, Masuko $T$ and Hashimoto $Y$ (1986) Inhibition of tumor cell growth in vitro by murine monoclonal antibodies that recognize a proliferation-associated cell surface antigen system in the rat and the human. Cancer Res 46, 1478-1484.

31. Yagita H, Masuko T, Takahashi N and Hashimoto Y (1986) Monoclonal antibodies that inhibit activation and proliferation of lymphocytes: I. Expression of antigen on monocytes and activated lymphocytes. J Immunol 136, 2055-2061 